\title{
Agroclimatic indices and phenology of pigeonpea [Cajanus cajan (L.) Millsp.] in relation to its yield
}

\author{
SUKHPREET KAUR SIDHU ${ }^{1 *}$, JAGMEET KAUR $^{2}$ and INDERJIT SINGH ${ }^{2}$ \\ ${ }^{1}$ Department of Botany, ${ }^{2}$ Department of Plant Breeding and Genetics, \\ Punjab Agricultural University, Ludhiana 141004, Punjab, India \\ *Corresponding author Email: preetsidhu-cobsbot@pau.edu
}

\begin{abstract}
A field experiment was conducted to study the influence of temperature, sunshine hours, day length and phosphorus (P) on phenology of four pigeonpea cultivars (PAU881, AL201, ICPL88039 and MN5) during Kharif seasons of 2014 and 2015 at Punjab Agricultural University, Ludhiana. The results of present investigation indicated that accumulation of growing degree days (AGDD), accumulated photo (APTU) and helio thermal unit (AHTU) was more in cultivar AL201 followed by ICPL88039, PAU881 and MN5for all phenophasic stages.Significant positive correlation was found between accumulated photothermal unit at maturity, pods per plant, seed per pod, 100-seed weight and yield. Path coefficient analysis revealed that pods per plant, grain per pod and AGDDM contributed more directly and indirectly to yield so; direct selection of these variables may be beneficial for more seed yield under no added $P$ condition.Cultivars AL201and ICPL88039 were significantly better than MN5 while PAU881 were on par with AL201 for all phenophases stages.
\end{abstract}

Key words: Phenological stages, AGDD, APTU and AHTU

Change in temperature, sunshine hours, day length, and soil mineral nutrient (availability and supply) influence the phenophasic development of crop.Abiotic and climatic factors are the major determinants of the productivity of crop under limited resources. Sowing time, seed germination, physiological and metabolic processes of plant life are controlled by temperature and nutrients availability (Aggarwal et al. 2016). Phenological development from sowing to physiological maturity is dependent on the accumulation of thermal units above threshold or base temperature. Aslow process of developmental events provides longer growing period and gives opportunity for the plant parts to survive with more number of pods and grains per pod.The specific temperature requirement of plants such as below $10^{\circ} \mathrm{C}$ or above $25^{\circ} \mathrm{C}$, the optimum $\left(12\right.$ to $\left.25^{\circ} \mathrm{C}\right)$ alter phenology, growth and development and finally reduce the yield (Hakim et al. 2012). Heat use efficiency depicted that the heat utilized to produce one unit of plant biomass (Rajbongshi et al.2016). Heat and photoperiodic units are considered as the fundamental units used to examine the phenology of crops over climatic variations (Sreenivas et al. 2010). A positive significant correlation occurs between weather variables and plant growth, phenology and yield, Path analysis is an effective method to evaluate direct and indirect variables of yield. This experiment was conducted to study morpho-phenology of pigeonpea cultivars under varied environments. Pearson correlation and path coefficient analysis were used as an index to screen the variables related with grain yield.

\section{MATERIALS AND METHODS}

Field experiment was conducted in the experimental area of the Pulses section, Department of Plant Breeding and Genetics, Punjab Agricultural University,Ludhiana during two kharif season (2014 and 2015). The soil was loamy sand with alkaline $\mathrm{pH}(7.5$ and 7.8$)$, available $\mathrm{P}(9.6$ and $11.9 \mathrm{~kg}$ acre $^{-1}$ ) and available potassium (96 and $87 \mathrm{~kg} \mathrm{acre}^{-1}$ ). The meteorological data was recorded during two crop seasons by School of Climate Change and Agrometeorology, Punjab Agricultural University; Ludhiana.

Four pigeonpea cultivars namely PAU881, AL201, ICPL88039 and MN5 were sown with two treatments [no added $\mathrm{P}$ and recommended dose of $\left.\mathrm{P}\left(40 \mathrm{kgha}^{-1}\right)\right]$ in three replications. The crop was sown as per recommended package of practices. The phenological events viz: days to flowering initiation (FI), days to $50 \%$ flowering (FF), days to pod initiation (PI) and days to physiological maturity (M) were 
recorded by visual observation on tagged five plants per replication from each plot.All agro-climatic indices namely growing degree days, heilo-thermal unit and photo-thermal units were calculated following Singh et al. (1990) and Nuttonson (1948).

Heat use efficiency(HUE) was computed using the following formula (Aggarwal et al. 2016).

HUE $=$ Grain yield/GDD

Growing degree days, helio-thermal units and photothermal units were accumulated from a particular date of phenophase to give accumulated indices.

\section{Statistical analysis}

Data related to AGDD, APTU and AHTU were statistically analyzed by SAS version 9.3 software and means were compared using Tukey comparison test (data pooled for both $\mathrm{P}$ treatments and years). Polynomial regression analysis was carried out using Microsoft Office Excel 2007. Pearson correlation coefficient and path analysis was done by SPSS16.0 software. Path diagram was designed by using correlation coefficient and direct path values of path correlation coefficient.

\section{RESULTS AND DISCUSSION}

\section{Days taken and accumulated agroclimatic indices}

Cultivars AL201 and ICPL88039 took more days to flower initiation while MN5 took lesser days in both the experimental years. For $50 \%$ flowering the maximum days were taken by AL201 followed by ICPL88039 cultivar. For pod initiation andattainment of physiological maturity cultivar ICPL88039 more number of days took than AL201, PAU881 and MN5 (Table 1).Accumulated growing degree days (AGDD) required for flower initiation and 50\% flowering was maximum in AL201 and ICPL88039. For pod initiation and attainment of physiological maturity significantly more AGDD were accumulated in ICPL88039 as compared to other cultivars and on par with AL201 for maturity. Cultivar MN5 accumulated significantly lesser growing degree days for all the phenophasic stages. In both years, ICPL88039 having longer duration used highest growing degree days to attain maturity. Statistically higher heat use efficiency (HUE) was found to be in PAU881 $\mathrm{kgha}^{-10} \mathrm{Cday}^{-1}$ (Fig. 1). There was significant difference in AGDD at flower initiation, 


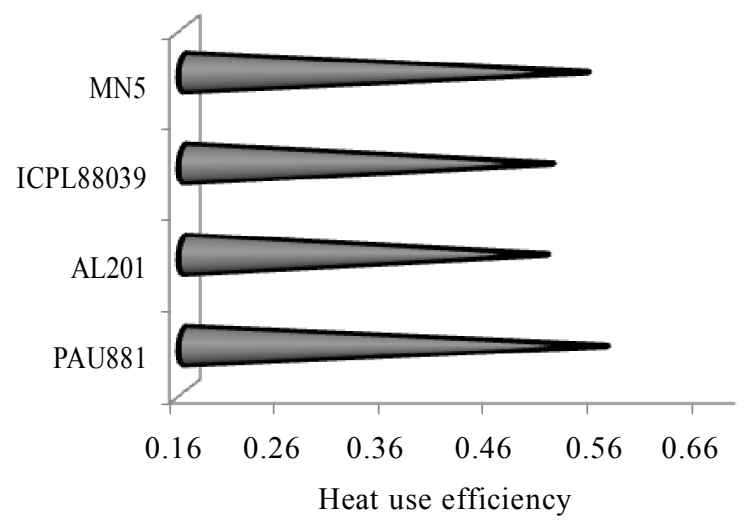

Fig 1: Heat use efficiency required for maturity of pigeonpea (Data pooled for both $\mathrm{P}$ treatments and years)

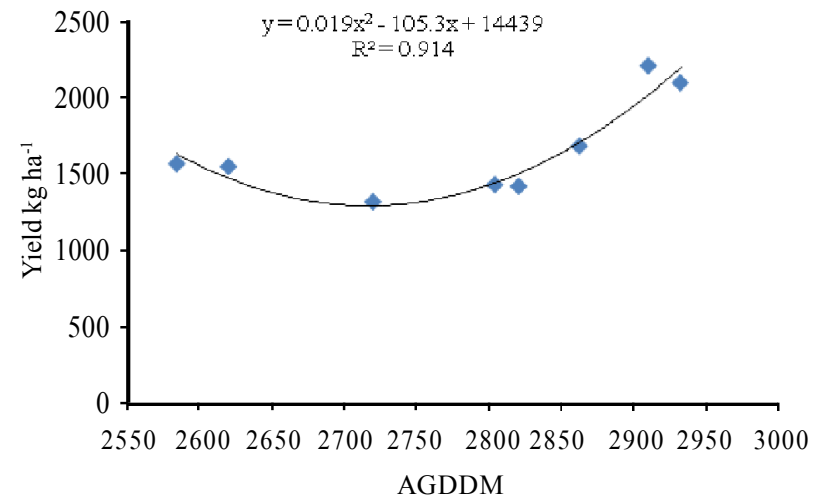

Fig 2: Polynomial relationship of pigeonpea cultivars between yield and accumulated growing degree days at maturity (AGDDM) under both $P$ treatments

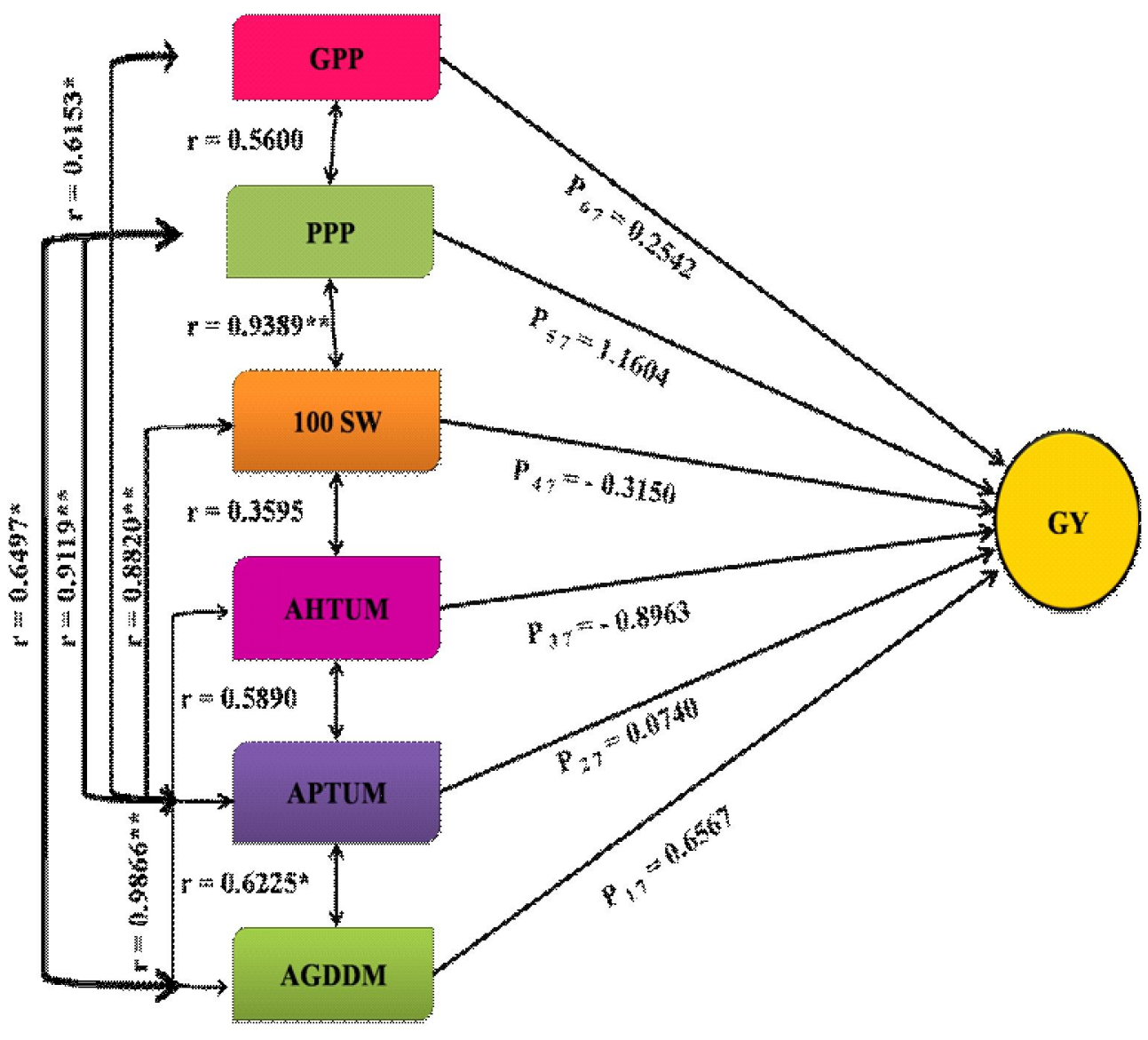

Fig 3: Path coefficient diagram showing the direct effects of grain yield (GY), accumulated growing degree days at maturity (AGDDM), accumulated photothermal unit at maturity (APTUM), accumulated helio-thermal units at maturity (AHTUM), 100- seed weight (100 SW), pods per pod (PPP) and grain per pod (GPP) under no added P condition.

$50 \%$ flowering, pod initiation and physiological maturity among cultivars while there was no significant difference between P treatments. Difference in AGDD at maturity was significant among cultivars and treatments. The results are in conformity with the findings of Chauhan et al. (1992).
The photo (APTU) and helio thermal unit (AHTU) accumulation varied from flower initiation to physiological maturity stage in all the cultivars. These variations were similar to that obtained with AGDD. All the cultivars significantly differed from each other under both treatments 
Table 2: Correlation coefficient between accumulateda groclimatic indices at maturity, yield attributes and grain yield

\begin{tabular}{ll}
\hline Traits & Correlation with grain yield \\
\hline AGDDM & 0.5697 \\
APTUM & $0.8916^{* *}$ \\
AHTUM & 0.5013 \\
100-seed weight & $0.9441^{* *}$ \\
Pod per plant & $0.9640^{* *}$ \\
Grain per pod & $0.6481^{*}$ \\
\hline
\end{tabular}

** Correlation is significant at the 0.01 level

* Correlation is significant at the 0.05 level

and years. There was significant $(P<0.01)$ difference in AHTU and APTU at flowering initiation, 50\% flowering, pod initiation and physiological maturity among cultivars (Table 1).

\section{Correlation coefficient and path analysis}

The correlation between seed yield of pigeopea and agrometeorlogical indices accumulated at maturity (AGDDM, APTUM and AHTUM) and yield attrbutes (pods per plant, 100 seed weight and seed per pod), showed that APTUM has highly significal positve correlation $\left(\mathrm{r}=0.8916^{* *}\right)$ (Table 2$)$. Similerly the grain yield was significantly positively correlated with APTUM $\left(\mathrm{r}=0.8916^{* *}\right)$, pods per plant $\left(\mathrm{r}=0.9640^{* *}\right)$, and 100 -seed weight $\left(\mathrm{r}=0.9441^{* *}\right)$. The correlations AGDD $(r=0.5697)$ of and AHTU $(r=0.5014)$ however, were non significant (Table 2). A significant positive polynomial relationship was obtained between seed yield and accumulated growing degree days $\left(\mathrm{R}^{2}=0.914\right)$ at maturity under both $\mathrm{P}$ treatment conditions (Fig. 2). The seed yield had significant positive correlation with accumulated growing degree days, accumulated photothermal unit (Kumar et al. 2008; Ratnam et al. 2015), accumulated thermal unit (Hundal et al. 1997).

A direct and indirect effect of different variables with seed yield of pigeopea was determined by path coefficient analysis. Yield as a dependent variable in path coefficient analysis revealed that all traits except AHTUM and 100 seed weight showed positive direct effect. The pods per plant $\left(\mathrm{P}_{57}=1.1604\right)$ had highest significant direct effect on yield followed by AGDD $\left(\mathrm{P}_{17}=0.6567\right)$ and grain per pod $\left(\mathrm{P}_{67}=\right.$ 0.2542). Direct effect of AHTUM $\left(\mathrm{P}_{37}=-0.8963\right)$ was negative and it contribute indirectly stronger via pod per plant $\left(\mathrm{r}_{35} \mathrm{P}_{37}=0.6953\right)$ on yield (Fig. 3). APTUM showed positive less direct effect $\mathrm{P}_{27}=0.074$ with an more positive indirect effect via pods per plant $\left(\mathrm{r}_{25} \mathrm{P}_{27}=1.0581\right)$, AGDDM $\left(\mathrm{r}_{21} \mathrm{P}_{2}\right.$ $\left.{ }_{7}=0.4088\right)$, grain per pod $\left(\mathrm{r}_{26} \mathrm{P}_{27}=0.1564\right)$ and negative indirect effect via 100 seed weight $\left(r_{24} P_{27}=-0.2778\right)$, $\operatorname{AHTUM}\left(\mathrm{r}_{23} \mathrm{P}_{27}=-0.5279\right)$ on yield. Path analysis indicated that days to maturity, number of pods per plant, seed weight, and morphological parameters had positive direct influence on yield per plant in pigeonpea.

\section{REFERENCES}

Aggarwal, N., Singh, A. and Singh, S. P. (2016) Heat utilization and radiation interception in transplanted rice (Oryza sativa L.) in relation to seedling age.J. Agrometerol., 18 (1): 93-96.

Chauhan, Y.S., Johanson, C. and Venkataratnam, N. (1992) Effect of phosphorus deficiency on phenology and yield components of short duration pigeon pea. Tropical Agri., 69: 235-238.

Hakim, M.A., Hossain, A., Teixeira, D., Silva, J.A.,Zvolinsky, V.P., Khan, M.M. (2012) Yield, protein and starch content of 20 wheat (Triticum aestivum L.) genotypes exposed to high tempera-ture under late sowing conditions. $J$. Sci. Res., 4: 477-489.

Hundal, S.S., Singh, R. and Dhaliwal, L.K.(1997)Agroclimatic indices for predicting phenology of wheat ( Triticum aestivum) in Punjab. Indian Agri. Sci., 67(6):265-268.

Kumar, A.,Pandey, V., Kumar, M. and Shekh. (2008) Correlation study in soybean (Glycine max[L] Mirrll) with response to prevailing weather parameters, agrometerological indices to seed and stover yield at Anand. AmericanEur. Agron., 1(2): 31-33

Nuttonson, M.Y.(1955). "Wheat climatic relationship and use of phenology in ascertaining the thermal and photothermal requirements of wheat". American Institution of Crop Ecology, Washington DC.

Rajbongshi, R., Neog, P., Sarma, P.K., Sarmah, K., Sarma, M.K., Sarma, D. and Hazarika, M. (2016). Thermal indices in relation to crop phenology and seed yield of pigeon pea (cajanus cajan L millsp.) grown in the north bank plains zone of Assam. Mausam, 67(2) 397-404 
Singh, G., Narwal, S.S., Rao, V.U.M. and Dhaiya, D.S. (1990). Effects of sowing date on requirement of growing degree days, heliothermal units and photothermal units on phenology of winter maize (Zea mays). Indian J. Agric.

Sci., 60(11): 723-731.
Sreenivas, G., M. Devender Reddy and D. Raji Reddy. (2010). Agro-meteorological indices in relation to phenology of aerobic rice. J. Agrometerol., 12(2): 241-244. 